\title{
Seasonal Patterns of Spore Deposition of Heterobasidion Species in Four Forests of the Western Alps
}

\author{
Paolo Gonthier, Matteo M. Garbelotto, and Giovanni Nicolotti
}

First and third authors: Department of Exploitation and Protection of the Agricultural and Forestry Resources-Plant Pathology, University of Torino, Via L. da Vinci 44, I-10095 Grugliasco, Italy; and second author: Department of Environmental Science, Policy and ManagementEcosystem Sciences Division, University of California at Berkeley, 151 Hilgard Hall, Berkeley 94720. Accepted for publication 15 February 2005.

\begin{abstract}
Gonthier, P., Garbelotto, M. M., and Nicolotti, G. 2005. Seasonal patterns of spore deposition of Heterobasidion species in four forests of the western Alps. Phytopathology 95:759-767.

Patterns of spore deposition by Heterobasidion species were studied between the spring of 1998 and December 2000 in four forests in the western Alps using woody traps. The maximum spore deposition rate (DR) ranged from 169 to 1,550 spores $\mathrm{m}^{-2} \mathrm{~h}^{-1}$. Although spores were captured from February to October at most sites, inoculum concentration

pling. Approximately 1,200 spores were isolated and identified at the species level by polymerase chain reaction-based methods. Single-spore isolates were consistently clampless, indicating the sampled airspora was almost exclusively composed of haploid basidiospores. No significant variations of basidiospore frequencies were detected for either $\mathrm{H}$. abietinum or H. annosum among sampling periods. However, the frequency of $H$. parviporum spores was always significantly higher in the summer. These findings suggest different patterns of sporulation among Heterobasidion species.
\end{abstract} consistently peaked in the late summer or early fall. In one of the four study sites, similar patterns of DR were recorded in 2 years of sampling. A significant correlation $(r=0.654, P=0.001)$ was found between DR and the average minimum air temperature in the 4 weeks before sam-
Additional keywords: aerobiology, Spiniger meineckellus, spore dissemination.
Heterobasidion annosum (Fr.) Bref. sensu lato is a root and butt rot agent that severely affects coniferous forests worldwide. This pathogen is regarded as a species complex, comprising three intersterility groups in Europe $(3,17)$, recently named $H$. parviporum Niemelä \& Korhonen, $H$. abietinum Niemelä \& Korhonen, and $H$. annosum sensu stricto (26). These species, although defined on the basis of partial reproductive isolation and morphology $(4,5,17,21)$, are also characterized by differences in pathogenicity on a range of hosts $(3,18,27,42)$. In Europe, $H$. parviporum primarily causes butt rots in Norway spruce (Picea abies (L.) Karst.), but it has also been reported to kill Scots pine (Pinus sylvestris L.) saplings. H. abietinum is commonly associated with root or butt rots in trees of the genus Abies (e.g., silver fir-Abies alba Miller), while $H$. annosum sensu stricto is typically associated with mortality of trees in the genus Pinus, but it can also attack Picea, Juniperus, and certain hardwood trees (18).

Heterobasidion sp. primarily infects its hosts through fresh-cut stumps or wounds by means of airborne meiospores and is capable of secondarily spreading from tree to tree through root grafts and contacts $(30,41)$. Airborne infection through thinning stumps results in rapid and heavy infection of healthy stands in areas where Heterobasidion sp. is common $(28,43)$, and aids its spread into new areas (1). The availability of inoculum is a necessary prerequisite for primary infection since inoculum potential is directly correlated with infestation levels (20). Thus, understanding the seasonal patterns of sporulation in Heterobasidion populations is pivotal when formulating control strategies for the disease this pathogen causes.

Corresponding author: P. Gonthier; E-mail address: paolo.gonthier@unito.it

DOI: 10.1094/PHYTO-95-0759

(c) 2005 The American Phytopathological Society
Although infection levels vary depending on site across the Alpine range, the pathogen is a major problem in the western Alps, especially where Norway spruce and silver fir grow together or independently. Up to $90 \%$ disease incidence was reported in a study of a subalpine forest in the western Alps (10), and incidence levels in the four study sites ranged from 30 to $50 \%$ as previously reported (11).

Aerobiology and temporal dynamics of spore deposition of Heterobasidion spp. have been studied in North America and northern and central Europe since the early 1950s $(2,8,14,16$, $32,35,44)$. Seasonal trends in spore deposition have been found to vary greatly among different collecting periods within stands and among forests in different ecotypes. In Britain, for instance, infection occurs during most of the year $(20,33)$, while in central and northern Europe, the main infection periods are autumn and spring $(37,44)$ and summer $(2,16)$, respectively. Regional differences in seasonal patterns of spore deposition have been reported in North America $(6,8,22,35)$. However, no information on temporal dynamics of spore deposition is available for the Alps and southern Europe. The area studied has the characteristic of being affected by all three European species of Heterobasidion, often in the same forest stand, allowing for an unprecedented comparison in sporulation patterns among the three. Because each of the three species is ecologically quite unique, with distinct host and geographic ranges (18), we designed this study not only to describe the overall temporal variation in spore production of the entire complex, but also to highlight potential differences among the three species.

Environmental factors, and in particular the weather, are known to affect the amount and timing of both spore production and deposition for many plant-pathogenic fungi (13). Air temperature, air humidity, and rainfall (RF) have been reported to influence spore production and deposition for Heterobasidion spp. (30). A positive correlation between temperature and spore deposition has 
been found in the northeastern United States and northern Europe $(16,38)$. High summer temperatures have been reported to reduce sporulation in the southern United States $(6,35)$. Hot dry weather in summer, combined with snow and low temperatures in winter, may locally restrict spore production to autumn $(29,36)$. Weather factors affect sporulation in different ways in each respective region $(30,31,44)$, complicating the task of developing local sporulation and spore dissemination models.

The goals of this study were (i) to determine temporal patterns of deposition of viable spores of Heterobasidion spp. in four forests of the western Alps; (ii) to compare temporal patterns of spore deposition among forests; (iii) to investigate the relationships between weather factors and the temporal patterns of inoculum availability; and (iv) to compare the patterns of deposition among the three European Heterobasidion species.

\section{MATERIALS AND METHODS}

Description of study sites. Spores deposition of Heterobasidion spp. was investigated in four naturally regenerated forests of the western Italian Alps: Chiusa Pesio, Jovençan, Charvensod, and Aymavilles (Table 1; Fig. 1). The stand at Chiusa Pesio (Piedmont) is characterized by a dominance of Abies alba including a significant component of various broad leaves such as Corylus avellana L., Laburnum alpinum (Miller) Berchtold et Presl, and Sorbus aucuparia L. The other three forests are located on the same mountain slope in the Aosta Valley. Jovençan is a forest dominated by A. alba, Charvensod is a pure Picea abies stand, and Aymavilles is a mixed A. alba-P. abies forest. The presence of other tree species is sporadic in these forests. Species list includes Larix decidua Miller and Pinus cembra L. at Charvensod, and Betula pendula Roth and Populus tremula L. in the remaining two forests, which are located at lower elevation. Soils are classified as Typic haplumbrept in Chiusa Pesio and Ochrepts/ Umbrepts in the other three sites (45). All forests are characterized by several large, even-aged groups of trees, resulting in stands that, as a whole, can be considered uneven-aged. Silvicultural treatments are similar at all sites with precommercial thinnings occurring every 15 years in Chiusa Pesio and every 20 years in the other sites. On average, thinning is light at all sites and results in the cutting of $10 \%$ or less of the entire timber volume.

Chiusa Pesio is in close proximity to the Ligurian sea and the climate is characterized by mild temperatures and abundant RF that peaks in May and November. The other three sites are characterized by a colder, subcontinental climate with low average annual RF, with the highest precipitation occurring in October and November. Information about the airborne inoculum composition of Heterobasidion species was previously documented for the study sites (11).

Spore sampling. In each forest, two permanent plots were established at a distance of $100 \mathrm{~m}$ from one another as described previously (11). A plot comprised three transects, each including three sampling points placed along the transects at 7-m intervals, resulting in a plot size of approximately 0.1 ha. Spores of Heterobasidion spp. were trapped using a modified version of the wood-disk exposure method $(14,34)$. Freshly cut wood disks of about 11 to $13 \mathrm{~cm}$ diameter, obtained from healthy spruce (Charvensod and Aymavilles) and fir (Chiusa Pesio and Jovençan), were sprayed, after bark removal, with $65 \%$ ethanol and placed onto a wet filter paper disk in a petri dish (11). One open petri dish per sampling point was placed on the ground or on snow from March 1998 to December 2000. Disks were exposed for approximately $24 \mathrm{~h}$ starting at about 8:00 a.m. Three closed petri dishes were included as controls at each collection time to check for possible contamination caused by either Heterobasidion isolates already present in the wood disks or by airborne spores that may have landed on the wood during trap preparation. In the first year, seasonal samples (one per season per site) were taken earlier in lower elevation sites. The first sampling (spring) was performed in March 1998 at Chiusa Pesio, in May at Jovençan and Aymavilles, and in June at Charvensod. A summer sampling was made in July at Chiusa Pesio, in August at Jovençan and Aymavilles, and in September at Charvensod. Fall samples were taken in October at Chiusa Pesio and Aymavilles, and in November at the other two sites. A winter sampling was conducted in all the forests in February 1999. Starting in March 1999, woody spore samplers were exposed at all sites at the beginning of each month. Spore sampling ended in August 2000, except for Charvensod and Aymavilles, where sampling was concluded in March and December 2000, respectively. Spore trappings were performed on calm days and were delayed when wind speed, measured at the beginning of each collection time by a portable anemometer (DO 9847K, Delta OHM s.r.l., Caselle di Selvazzano, Italy), exceeded $3.0 \mathrm{~m} \mathrm{~s}^{-1}$.

After exposure, filter papers contained in the petri dishes were replaced and dampened with $3 \mathrm{ml}$ of sterile water. Wood disks were sprayed with a benomyl solution $(0.010 \mathrm{~g}$ of benomyl,

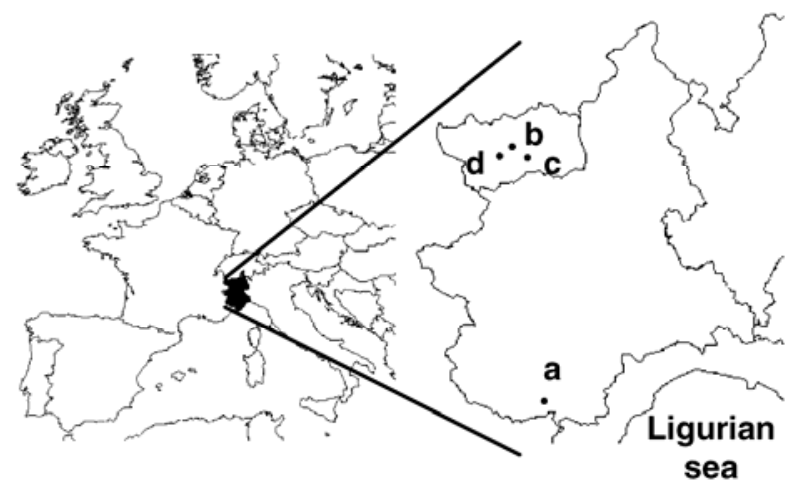

Fig. 1. Geographical location of the four study sites: Chiusa Pesio (a), Jovençan (b), Charvensod (c), and Aymavilles (d).

TABLE 1. Forest site locations and main stand characteristics

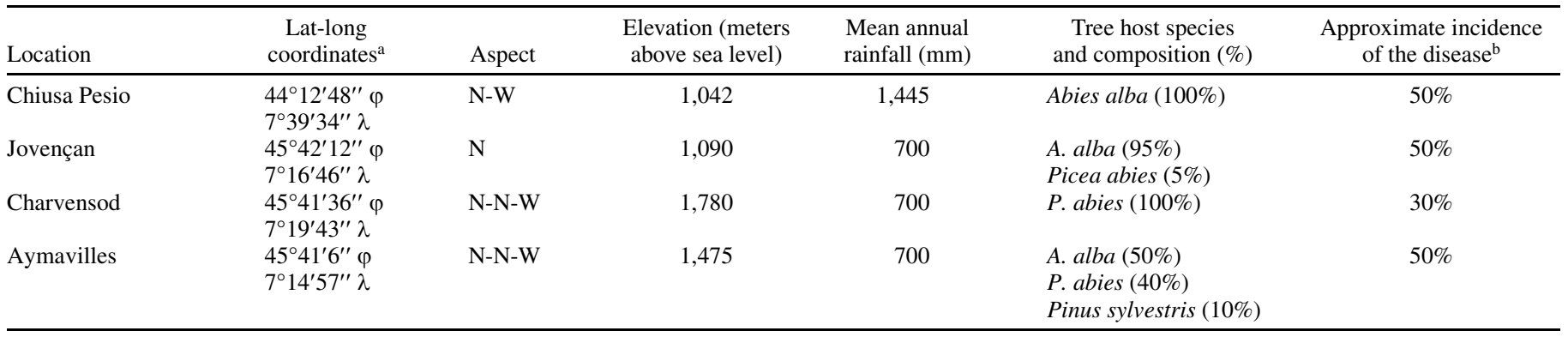

a World Geodetic System 1984 (WGS84) datum.

${ }^{\mathrm{b}}$ This estimate was based on the frequency of stumps displaying incipient and advanced decay on the stump top, as assessed by examining the stump surface immediately after last thinning. 
$500 \mu \mathrm{l}$ of methanol, and 1 liter of sterile water) and incubated at $24^{\circ} \mathrm{C}$ for 5 to 7 days.

Disks were examined under a dissection microscope $(\times 20)$ for colonies of Spiniger meineckellus (A.J. Olson) Stalpers, the conidial stage of the fungus. Colonies were counted and the number of spores was determined under the assumption that each colony resulted from deposition of one viable spore $(14,34)$.

Weather monitoring. Weather measurements were taken in the forest of Aymavilles from March 1999 to the conclusion of the study. Air temperature and relative air humidity $(\mathrm{RH})$ were recorded continuously at the center of each plot using a hygrothermograph (MT 1500, SIAP, Bologna, Italy) installed in a weather shelter at $1.5 \mathrm{~m}$ above ground. RF was measured at the same location with a 7-day rain gauge (UM 8100, SIAP). In snowy winter conditions, snow height was used as a proxy for RF. Average values of the weather data were calculated at 1-h intervals.

Isolation and typing of spores of Heterobasidion spp. Isolations of putative single-spore colonies of Heterobasidion spp. were performed from disks exposed during the first year at all sites, and from trappings performed until July 2000 at Aymavilles. This site was selected for closer investigation because of the previously documented presence of all three European species of Heterobasidion (11).

Fungal colonies were isolated under a dissecting microscope $(\times 20)$ by transferring infected wood pieces onto $5-\mathrm{cm}$ petri dishes containing a selective medium for Heterobasidion (19). When three or more colonies per disk were visible, three colonies were randomly chosen for isolation. All isolates were subsequently grown at room temperature on $5-\mathrm{cm}$ petri dishes with malt extract agar ( $20 \mathrm{~g}$ of malt extract, $20 \mathrm{~g}$ of glucose, $2 \mathrm{~g}$ of peptone, $20 \mathrm{~g}$ of agar, and 1 liter of distilled water). To determine the ploidy of colonies generated from spores, presence or absence of clamp connections was checked on a subset of $15 \%$ of all isolates by direct observation of cultures in inverted petri dishes at $\times 300$ magnification. Isolates displaying clamps at the septa were considered to be heterokaryotic $(n+n)$, while clampless isolates were regarded as homokaryons $(n)$. DNA extractions were made by a modified CTAB (cetyltrimethyl-ammonium bromide) extraction method (11).

Three methods were used to identify at the species level the isolates obtained during the first year of the study: (i) a taxonspecific competitive-priming-polymerase chain reaction (PCR) (9) combined with a PCR-mediated detection of species-specific introns in the ML5-ML6 DNA region of the mitochondrial large ribosomal RNA (mt LrRNA) gene; (ii) a PCR restriction fragment length polymorphism on the internal transcribed spacer; and (iii) sexual compatibility tests with homokaryon testers of the three European species of Heterobasidion. Because method one was deemed extremely accurate at the end of the first year and in a previous study (11), the isolates obtained from the monthly trappings at Aymavilles were typed exclusively by a modified version of this method (10).

Data interpretation and analysis. Based on the area of each trap of approximately $0.01 \mathrm{~m}^{2}$, spore deposition values were standardized and reported as (i) number of viable spores per square meter per hour (deposition rate [DR]) and (ii) percentage of infected disks per experiment (infection frequency [IF]). While DR provides information on the quantity of airborne spores, IF may be a more appropriate measurement when analyzing the spatial distribution of spore depositions within stands. For each year, seasonal and monthly DR values were compared using a one-way analysis of variance design and Tukey's honestly significant difference test, considering values from transects as replicates.

Pearson product-moment correlation between DR and IF values was calculated for each stand, and simple linear regression analysis was used to determine the relationships between the two variables. An $\operatorname{Ln}(N+1)$ transformation was used to normalize the distribution of the residuals for DR data (Shapiro Wilk's statistics, $P>0.10)$. An arcsine transformation was employed for IF data.

Pearson product-moment correlation analyses were used to relate DR values from the four forests studied monthly since March 1999, and DR values from the first and the second year of monthly samplings at Aymavilles. In addition, at Aymavilles, correlation analyses were used to determine the effects on DR of the following weather variables: the daily minimum, mean, and maximum temperature $\left({ }^{\circ} \mathrm{C}\right)$; the daily minimum, mean, and maximum RH (\%); and the daily total RF (mm). DR values were correlated with the above weather variables recorded over the 2-day, 7-day, and 4-week periods before the sampling period. Average values were used for temperature and $\mathrm{RH}$, while cumulative values were employed for RF. Bonferroni's correction for multiple tests was used to adjust threshold levels of significance of correlation coefficients.

To define temporal trends of spore deposition for each species of Heterobasidion, both absolute frequencies and relative fre-

TABLE 2. Analysis of variance comparing spore deposition rate values of Heterobasidion spp. from different sampling periods in four forest stands of the western Italian Alps

\begin{tabular}{|c|c|c|c|c|c|c|c|}
\hline Forest & Year $^{\mathrm{a}}$ & Source & $\mathrm{df}$ & Sum of squares & Mean square & $F$ value & $P$ \\
\hline \multirow[t]{5}{*}{ Chiusa Pesio } & \multirow[t]{2}{*}{ A } & Effect & 3 & $10,685.83$ & $3,561.94$ & 1.89 & 0.1637 \\
\hline & & Error & 20 & $37,679.31$ & $1,883.97$ & $\ldots$ & $\ldots$ \\
\hline & B & Effect & 9 & $1.24 \times 10^{7}$ & $1.38 \times 10^{6}$ & 214.88 & $<0.0001$ \\
\hline & \multirow[t]{2}{*}{$\mathrm{C}$} & Effect & 7 & $27,912.70$ & $9,987.53$ & 16.20 & $<0.0001$ \\
\hline & & Error & 40 & $9,843.49$ & 246.09 & $\ldots$ & $\ldots$ \\
\hline \multirow[t]{4}{*}{ Jovençan } & \multirow[t]{2}{*}{ A } & Effect & 3 & $7.49 \times 10^{5}$ & $2.49 \times 10^{5}$ & 91.09 & $<0.0001$ \\
\hline & & Error & 20 & $54,844.90$ & $2,742.24$ & $\ldots$ & $\ldots$ \\
\hline & \multirow[t]{2}{*}{$\mathrm{C}$} & Effect & 7 & $23,291.41$ & $3,327.34$ & 4.84 & 0.0005 \\
\hline & & Error & 40 & $27,485.62$ & 687.14 & $\ldots$ & $\ldots$ \\
\hline \multirow[t]{5}{*}{ Charvensod } & \multirow[t]{2}{*}{ A } & Effect & 3 & $1.25 \times 10^{5}$ & $41,772.27$ & 8.89 & 0.0006 \\
\hline & & Error & 20 & $93,958.93$ & $4,697.95$ & $\ldots$ & $\ldots$ \\
\hline & \multirow[t]{2}{*}{ B } & Effect & 9 & $33,036.27$ & $3,670.70$ & 18.69 & $<0.0001$ \\
\hline & & Error & 50 & $9,823.19$ & 196.46 & $\ldots$ & $\ldots$ \\
\hline & $\mathrm{C}$ & 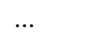 & $\ldots$ & & & . & \\
\hline & \multirow[t]{2}{*}{$\mathrm{C}$} & Effect & 11 & $4.56 \times 10^{5}$ & $41,430.73$ & 15.36 & $<0.0001$ \\
\hline & & Error & 60 & $1.62 \times 10^{5}$ & $2,697.29$ & $\ldots$ & $\ldots$ \\
\hline
\end{tabular}

a A, B, and C refer to seasonal samplings of 1998 to 1999 , monthly samplings of 1999, and monthly samplings of 2000, respectively. 
quencies (percentage of spores of a given species relative to the total number of spores identified) were used. At Aymavilles, the data from two consecutive months were pooled. The MannWhitney $U$ test was employed to compare absolute frequencies for each species from different collection periods. $\chi^{2}$ tests and contingency tables were used to compare the relative abundance of spores of each Heterobasidion species obtained in different sampling periods. Spearman's rank-order correlation test was used to compare spore abundance of the three species in corresponding collection periods of 1998 to 1999 and 1999 to 2000. Statistical analyses were performed using the software Statistica (StatSoft Inc., Tulsa, OK).
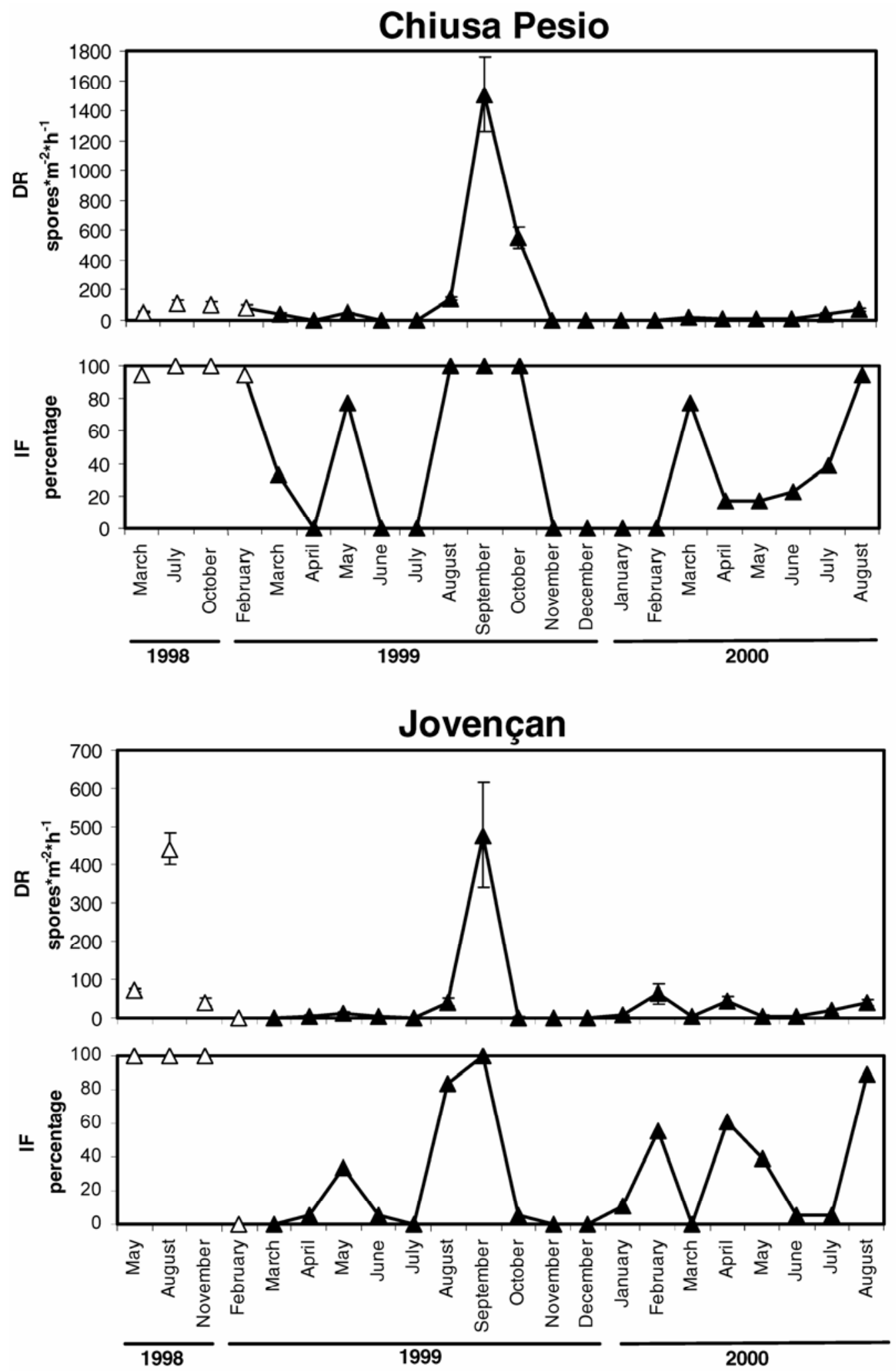

(Continued on next page)

Fig. 2. Seasonal and monthly variation of spore deposition of Heterobasidion spp. over the years 1998 to 2000 in four forest stands in the western Alps. Deposition rates (DR) are expressed as the mean number of spores per square meters per hour, and infection frequencies (IF) represent the percentage of wood disks infected by spores of the pathogen. Bars show standard errors. 


\section{RESULTS}

Spore deposition by all Heterobasidion spp. Spores of Heterobasidion spp. were collected on woody traps at all four study sites, while control disks were always uninfected.
Seasonal (1998 and 1999) data. Variation of DR values was highly significant in all stands, with the exception of Chiusa Pesio (Table 2). At this site, spores were trapped at each sampling time with a minimum IF of $94 \%$ (Fig. 2). At the other three sites, no spores were trapped during the winter

Charvensod
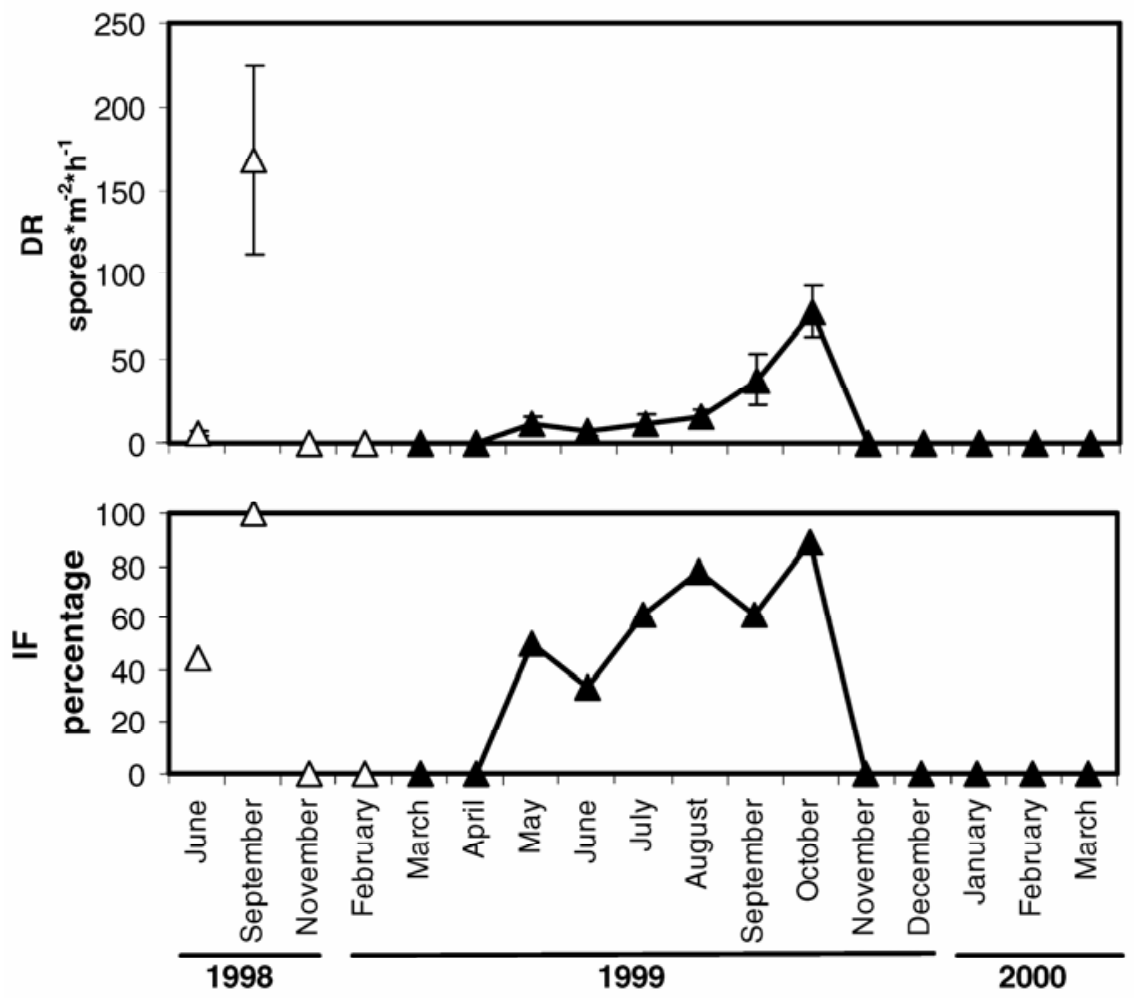

\section{Aymavilles}
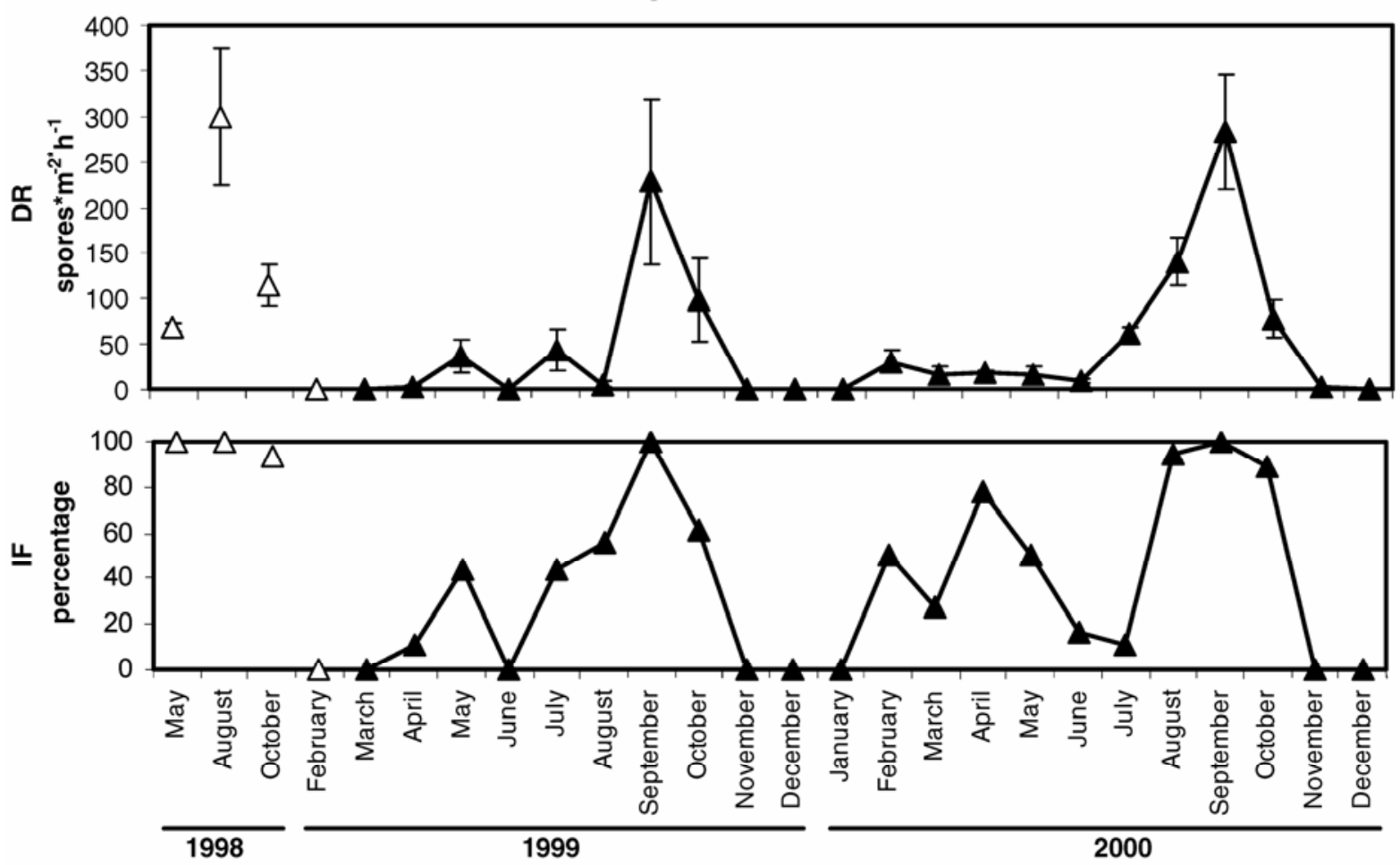

Fig. 2. (Continued from preceding page). 
sampling. Maximum DR values were recorded in the summer in all forests.

Monthly (1999 and 2000) data. Monthly DR values peaked in September to October, and then declined (Fig. 2). DR values from trappings performed during winter, spring, and early summer were very low or zero. Although high IF values were always reached when high DR values were recorded, even slight increases in DR values resulted in relatively high peaks for IF measurements. During 1999, IF increased in June or July, reached a peak (IF > 90\%) in August to October depending on the site, and then dropped to zero at all sites. The same pattern was evident in 2000. A smaller peak was attained around May at all sites and in both years.

Correlation between DR and IF was highly significant in all stands $(P<0.001)$, with $r$ ranging from 0.917 at Jovençan to 0.985 at Charvensod. In the regression of DR versus IF, intercept values did not significantly differ from zero at any site, and regression slopes did not significantly differ from one another. Regression analysis performed on pooled DR versus IF data (Fig. 3 ) indicated that IF values of 50 and $90 \%$ were attained when DR values were $>22$ and 231 spores $\mathrm{m}^{-2} \mathrm{~h}^{-1}$, respectively.

Temporal patterns of spore deposition were similar across all sites, both in terms of DR and IF. Significant correlations were found among all forests, with the exception of the JovençanCharvensod comparison (Table 3).

Monthly patterns of spore deposition in 1999 and 2000 at Aymavilles were well correlated with one another. Pearson's correlation coefficients for DR and IF were $0.718(P=0.013)$ and $0.759(P=0.007)$, respectively.

Abundance of spores produced by individual Heterobasidion spp. No clamp connections were found in $93 \%$ of analyzed cultures, suggesting that the majority of colonies were derived from basidiospores rather than from conidia. The remaining $7 \%$ was clamped, the likely result of mating of homokaryotic colonies generated by basidiospores landing near one another on the same trap. A total of 1,191 out of 1,232 isolates were successfully typed: 556 were $H$. parviporum (41\%), 421 were $H$. abietinum (43\%), and 214 (16\%) were H. annosum.

$H$. abietinum was the most frequent species recovered at the silver fir-dominated stands of Chiusa Pesio and Jovençan. In Charvensod, the dominant fungal species was $H$. parviporum. At this site, which had the highest elevation among the four studied, spore population was most concentrated in September (Fig. 4).
In Aymavilles (Fig. 5), the abundance of $H$. parviporum spores was significantly higher in August 1998, in May/June to September/October 1999, and in July 2000 than in the other two species. Spore production by $H$. parviporum and $H$. annosum showed a significant peak in the September/October 1999 sampling.

The proportion of spores of $H$. abietinum and $H$. annosum did not show significant variations over time at any of the sites. The same was true for $H$. parviporum in Chiusa Pesio and Jovençan. At Aymavilles, a significantly higher proportion of $H$. parviporum spores resulted in summer samplings relative to the other sampling periods of respective years $\left(\chi^{2} 26.17\right.$, df $=1, P<0.005$ in August 1998; $\chi^{2} 26.59$, df $=1, P<0.005$ in July to August 1999; and $\chi^{2} 10.10$, df $=1, P<0.005$ in July 2000). Relative fungal species abundance recorded in 1998 was significantly correlated to species abundance recorded in analogous periods of 1999 (Spearman $\rho=0.794, P=0.011$ ).

Effects of weather. Both the mean and minimum air temperature in the 4 weeks before sampling were significantly correlated with DR, with Pearson's correlation coefficients of 0.632 and 0.654 , respectively (Table 4$)$. DR was not correlated with maximum temperature.

Correlations between DR and RH were not significant. Basidiospore capture was positively, but only weakly, correlated with the amount of monthly RF.

\section{DISCUSSION}

The results presented in this study indicate that the airborne inoculum of Heterobasidion spp., although present starting in February at most sites, is higher in August to October, reaching a peak in September. This observation is true in terms of both DR and IF. A relative peak, lower than the one in late summer, appears in late spring at all sites. This peak is more evident when evaluating results in terms of IF than in terms of DR.

Correlation analyses using DR or IF values indicated that temporal trends of spore deposition were homogenous among forests. This is noteworthy because our sites were characterized by diverse climatic conditions (Chiusa Pesio versus the other three sites), disease incidence, and inoculum concentration. Our sampling at Aymavilles also showed that spore deposition patterns were similar year after year. These findings indicate that Heterobasidion spore dissemination follows consistent seasonal patterns, not just at the local, but at the larger regional scale. A peak in

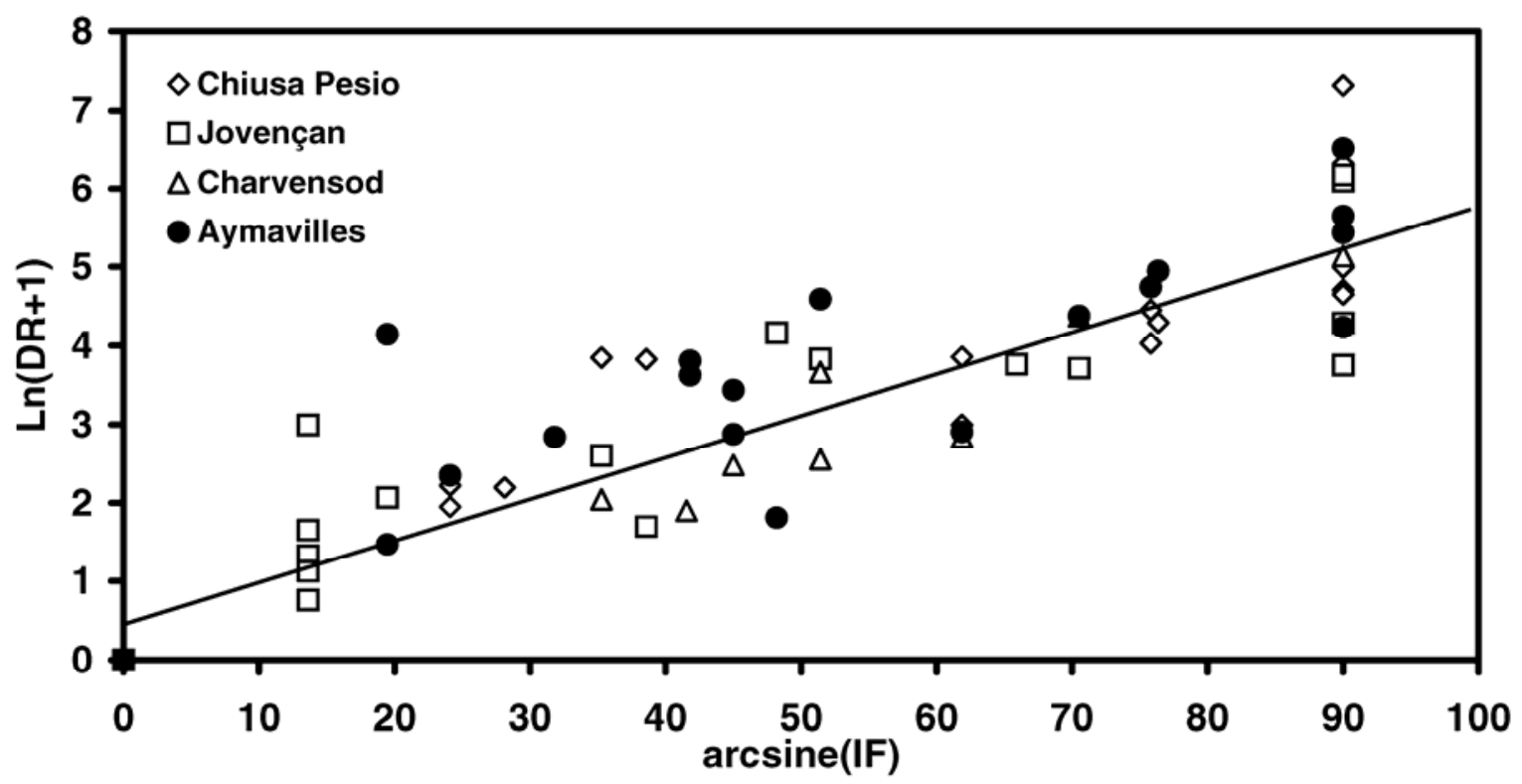

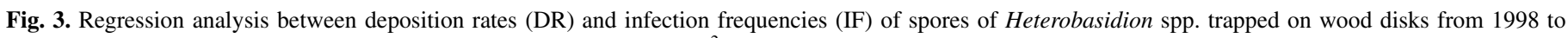
2000 in four Alpine forests. The regression line is based on pooled data $\left(r^{2}=0.875 ; P<0.001\right)$. 
spore deposition is not evident in the 1998 sampling at Chiusa Pesio. It is likely the peak was missed because of our limited sampling in that year.

A review of the literature suggests that differences in spore dissemination patterns are encountered when comparing different climatic zones $(2,20,33,37,44)$. In the western Alps, inoculum production is largely concentrated in a period of 2 to 3 months. The spore inoculum in winter, spring, and early summer is generally low, with concentration levels comparable to those found in healthy stands of northern Europe $(16,24)$. Our findings indicate (i) a marked seasonality of spore deposition and consequently of potential for infection of stumps and trees, and (ii) that the highest risk of infection may be concentrated in a relatively short period.

Data from Charvensod and Jovençan were not significantly correlated. However, the deposition patterns of the two sites were similar, with the exception of the main peak, which occurs a month later in Charvensod than in Jovençan. The two forests are on the same mountain slope, but the former site is approximately $700 \mathrm{~m}$ higher in elevation. Such lag in the presence of the peak can be explained by the more severe climatic conditions of the site at higher elevation.

The presence of airborne spores is a prerequisite for primary infection by most fungi (13), and the abundance of the airspora, often referred to as inoculum potential, is directly correlated with infection potential $(20,38,39)$. Actual infection is bound to be lower than the estimated infection potential for a variety of reasons, including environmental factors, virulence of fungal isolates, competition with other isolates and/or other fungi, and the ability of the host to fence off the colonization process.

The maximum DR values in our study ranged between 169 to 1,550 spores $\mathrm{m}^{-2} \mathrm{~h}^{-1}$, measured at Charvensod and Chiusa Pesio, respectively. These levels are comparable to the levels obtained from North America and Europe, using similar experimental approaches $(7,14,44)$. Because the heterogeneity in the surface of wood disks or stumps leads to differential germination success of the pathogen on different sectors $(12,23,25)$, it is likely that the actual concentration of airborne inoculum may be higher than that reported in this study.

DR and IF are correlated with each other, and both appear to be suitable indicators for describing the spore deposition process (Fig. 3). The relationship between the two variables is nonlinear. Large amounts of spores (i.e., over 230 spores $\mathrm{m}^{-2} \mathrm{~h}^{-1}$ ) would be necessary for $90 \%$ of traps to be infected. On the other hand, small increases in DR may lead to large increases in IF. When biological and environmental conditions are favorable to the pathogen, IF values may predict infection better than DR because each spore has a high chance of successfully causing infection. As conditions become less favorable to the pathogen, DR values may predict infection better than IF. In adverse conditions, in fact,

TABLE 3. Correlation of monthly patterns of spore deposition of Heterobasidion spp. among the four forest stands in 1999 to 2000

\begin{tabular}{|c|c|c|c|c|c|c|c|}
\hline \multirow[b]{3}{*}{ Stands } & & \multicolumn{6}{|c|}{ Pearson's correlation coefficient ${ }^{\mathrm{a}}$} \\
\hline & & \multicolumn{2}{|c|}{ Jovençan } & \multicolumn{2}{|c|}{ Charvensod } & \multicolumn{2}{|c|}{ Aymavilles } \\
\hline & & & $N$ & & $N$ & & $N$ \\
\hline \multirow[t]{2}{*}{ Chiusa Pesio } & $\mathrm{DR}^{\mathrm{b}}$ & $0.480 *$ & 18 & $0.691 * *$ & 13 & $0.622 * *$ & 18 \\
\hline & $\mathrm{IF}^{\mathrm{c}}$ & $0.580 *$ & $\ldots$ & $0.656^{*}$ & $\ldots$ & $0.662 * *$ & $\ldots$ \\
\hline \multirow[t]{2}{*}{ Jovençan } & DR & $\ldots$ & $\ldots$ & $0.337 \mathrm{NS}$ & 13 & $0.579 *$ & 18 \\
\hline & IF & $\ldots$ & $\ldots$ & $0.428 \mathrm{NS}$ & $\ldots$ & $0.832 * *$ & $\ldots$ \\
\hline \multirow[t]{2}{*}{ Charvensod } & DR & $\ldots$ & $\ldots$ & $\ldots$ & $\ldots$ & $0.675 *$ & 13 \\
\hline & IF & $\ldots$ & $\ldots$ & $\ldots$ & $\ldots$ & $0.657 *$ & $\ldots$ \\
\hline
\end{tabular}

a $* *$ And $*$ indicate significant at $P=0.01$ and 0.05 , respectively; $\mathrm{NS}=$ not significant.

${ }^{b}$ Deposition rate (DR) is the number of viable spores per square meter per hour; for analysis, values were transformed with the $\operatorname{Ln}(N+1)$ transformation.

c Infection frequency (IF) is the percentage of infected wood disks; for analysis, values were transformed with the arcsine transformation. successful infections by the pathogen may depend on the presence of multiple individuals.

DR values above 10 spores $\mathrm{m}^{-2} \mathrm{~h}^{-1}$ at the time of cutting significantly increase the risk of stump infection $(16,23)$. In our study, that threshold was exceeded in all stands 17 to 150 times. A previous study performed in Charvensod determined that $100 \%$ of stumps had been colonized (25).

A geographically limited range of dispersal of Heterobasidion basidiospores has already been suggested $(11,40)$; therefore, larger spore numbers would be expected where larger fruiting body production occurs. At Chiusa Pesio, the site where the highest levels of DR were recorded, basidiospore-producing fruiting bodies were several times more abundant than in the three other sites (data not shown).

The average minimum air temperature of the preceding 4-week period is the variable with the most significant correlation value with DR, and may thus be considered a suitable predictor for modeling Heterobasidion spore deposition. Positive correlations between temperature and basidiospore production have been previously reported (38). Our regression analysis (data not shown) indicated that at temperatures below $-5.5^{\circ} \mathrm{C}$, DR values are negligible. In Fennoscandia, the risk of stump infection at temperatures below $+5^{\circ} \mathrm{C}$ is nil (15), and the air temperature must be $>0{ }^{\circ} \mathrm{C}$ in
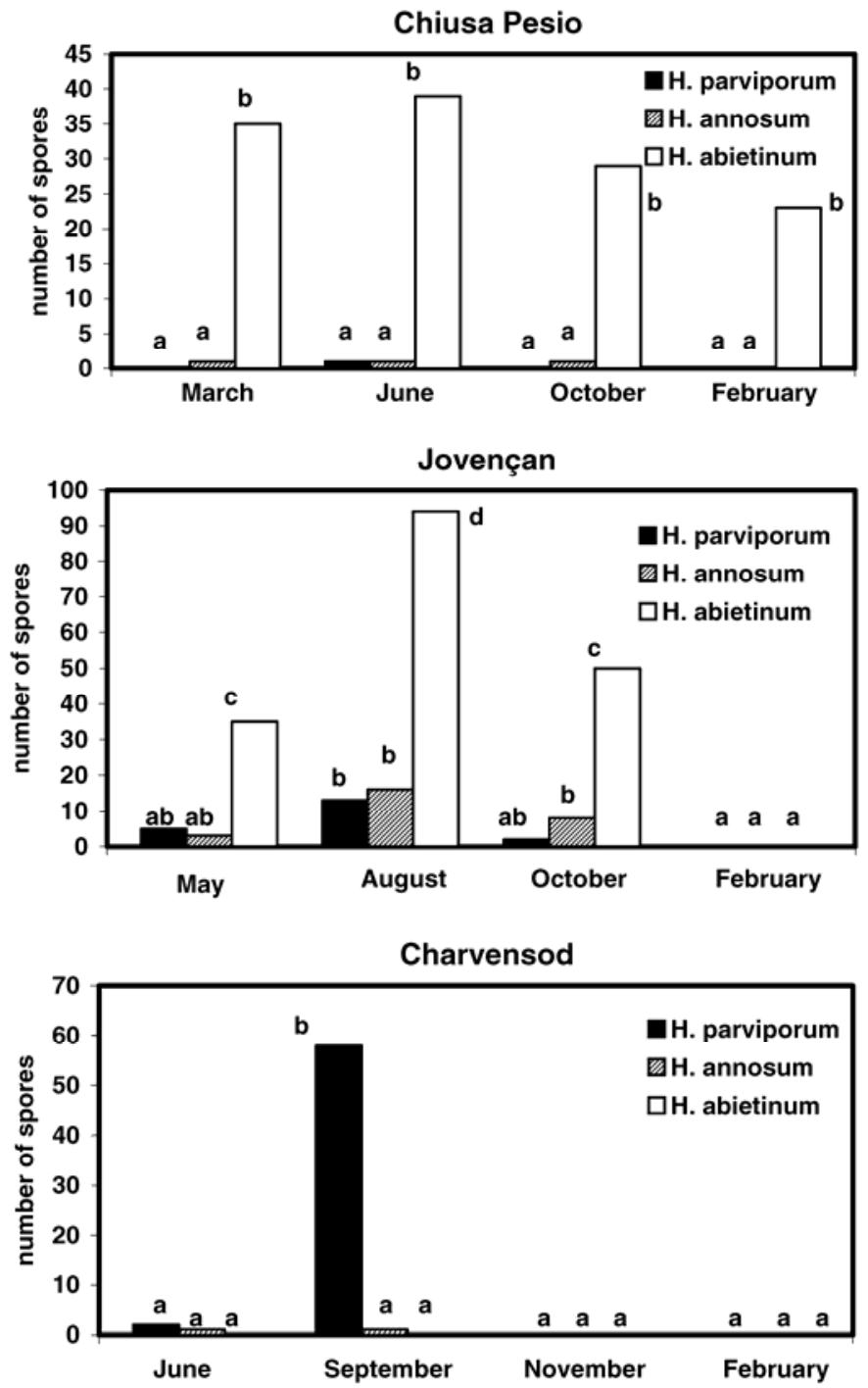

Fig. 4. Frequency of spores of the three species of Heterobasidion in three forests in the western Alps in different time periods determined with wood disk samples. Samplings were performed in 1998 and 1999. The abundance of spores was compared by the Mann-Whitney $U$ test $(n=418)$; bars with the same letter are not significantly different $(P \leq 0.05)$. 
order for spore production to occur, and above $+5^{\circ} \mathrm{C}$ to be abundant $(16,20,32)$. In our study, spore deposition stopped in autumn at a minimum monthly air temperature below $+5^{\circ} \mathrm{C}$ and occurred again in winter/spring when mean temperatures exceeded $+4^{\circ} \mathrm{C}$.

Further studies are needed to assess whether precipitation events, including snowfall, may influence release and deposition of Heterobasidion airborne spores. However, we agree with authors of previous studies $(16,38)$, that the low temperatures rather than the possible dispersal barrier posed by a snow cover may explain the lack of availability of inoculum during winter. Both in 1999 and 2000, spore deposition declined rapidly and stopped before the first snowfall. In California, spore production has been reported even in snowy conditions (14).

The fact that all three European Heterobasidion species are present at our study sites allows for a direct comparison among them. Our extended sampling at Aymavilles indicated that the numbers of spores of $H$. annosum and $H$. abietinum were always similar to one another and showed only small fluctuations throughout the year. On the other hand, sporulation by $H$. parviporum increased significantly during the summer. This was true in terms of both absolute number and relative abundance of spores. These patterns of spore deposition, which differentiated $H$. parviporum from the other two species, were analogous when comparing corresponding periods of different years. In areas where $H$. parviporum was not the dominant species, sharp changes in spore deposition were not recorded, potentially because such changes may have been partially masked by the abundance of other species (i.e., H. abietinum).

Our results show for the first time that different Heterobasidion species differ in their potential for spore dissemination even when found in the same forest. The ecological implications of these findings are numerous and deserve further studies. The presence of a rather short-lived but marked peak in spore production for H. parviporum appears as a useful adaptation for a pathogen species found at high altitudes and latitudes where favorable weather conditions may be limited to a short period in the summer months. The other two European Heterobasidion species are generally found in more mesic areas (18), where weather conditions may not be as harsh. Nevertheless, our results also provide valuable information that could be used to design silvicultural guidelines aimed at minimizing the risk of infection of trees by this pathogen. Based on our study, thinning operations in spring rather than in summer should result in a drop in infection of stumps of Norway spruce by H. parviporum. In the spring, in fact, not only were the DR values significantly lower than in other seasons but the relative abundance of $H$. parviporum was also lower when compared with the two other species. The opportune timing of thinning operations may be most useful within an integrated disease management program including preventive stump treatments, but it should be regarded as a pivotal tool for disease control in areas where stump treatments are not allowed or economical.

Winter thinning and logging operations have been used in Fennoscandia to take advantage of the low inoculum pressure during the cold season. The same approach may also be useful in the western Alps, where inoculum pressure is also very low in the winter months. Although winter operations may not be feasible at all sites in the Alps, their advantages include limiting infection of spruce stumps not only by $H$. parviporum but also by $H$. anno-

TABLE 4. Correlation coefficients of monthly deposition rates of spores of Heterobasidion spp. with weather variables (temperature [T], relative humidity $[R H]$, and rainfall $[R F]$ ) recorded daily for each of the 2-day, 7-day, and 4-week periods preceding the date of spore collection at Aymavilles from March 1999 to December 2000

\begin{tabular}{lccl}
\hline & \multicolumn{3}{c}{ Correlation coefficients $^{\mathrm{a}}$} \\
\cline { 2 - 4 } Variable & 2 days $^{\mathrm{b}}$ & 7 days $^{\mathrm{b}}$ & 4 weeks $^{\mathrm{b}}$ \\
\hline Mean T $\left({ }^{\circ} \mathrm{C}\right)$ & $0.425 \mathrm{NS}$ & $0.551 \mathrm{NS}$ & $0.632^{*}$ \\
Minimum T $\left({ }^{\circ} \mathrm{C}\right)$ & $0.388 \mathrm{NS}$ & $0.465 \mathrm{NS}$ & $0.654^{*}$ \\
Maximum T $\left({ }^{\circ} \mathrm{C}\right)$ & $0.412 \mathrm{NS}$ & $0.425 \mathrm{NS}$ & $0.450 \mathrm{NS}$ \\
Mean RH $(\%)$ & $0.321 \mathrm{NS}$ & $0.428 \mathrm{NS}$ & $0.245 \mathrm{NS}$ \\
Minimum RH $(\%)$ & $0.080 \mathrm{NS}$ & $0.196 \mathrm{NS}$ & $0.393 \mathrm{NS}$ \\
Maximum RH $(\%)$ & $0.513 \mathrm{NS}$ & $0.479 \mathrm{NS}$ & $0.009 \mathrm{NS}$ \\
RF $(\mathrm{mm})$ & $0.042 \mathrm{NS}$ & $0.136 \mathrm{NS}$ & $0.302 \mathrm{NS}$ \\
\hline
\end{tabular}

a * Indicates significant and NS = not significant, after Bonferroni's correction $(P=0.002)$.

$\mathrm{b}$ Average values were used for $\mathrm{T}$ and $\mathrm{RH}$, and cumulative values were employed for RF.

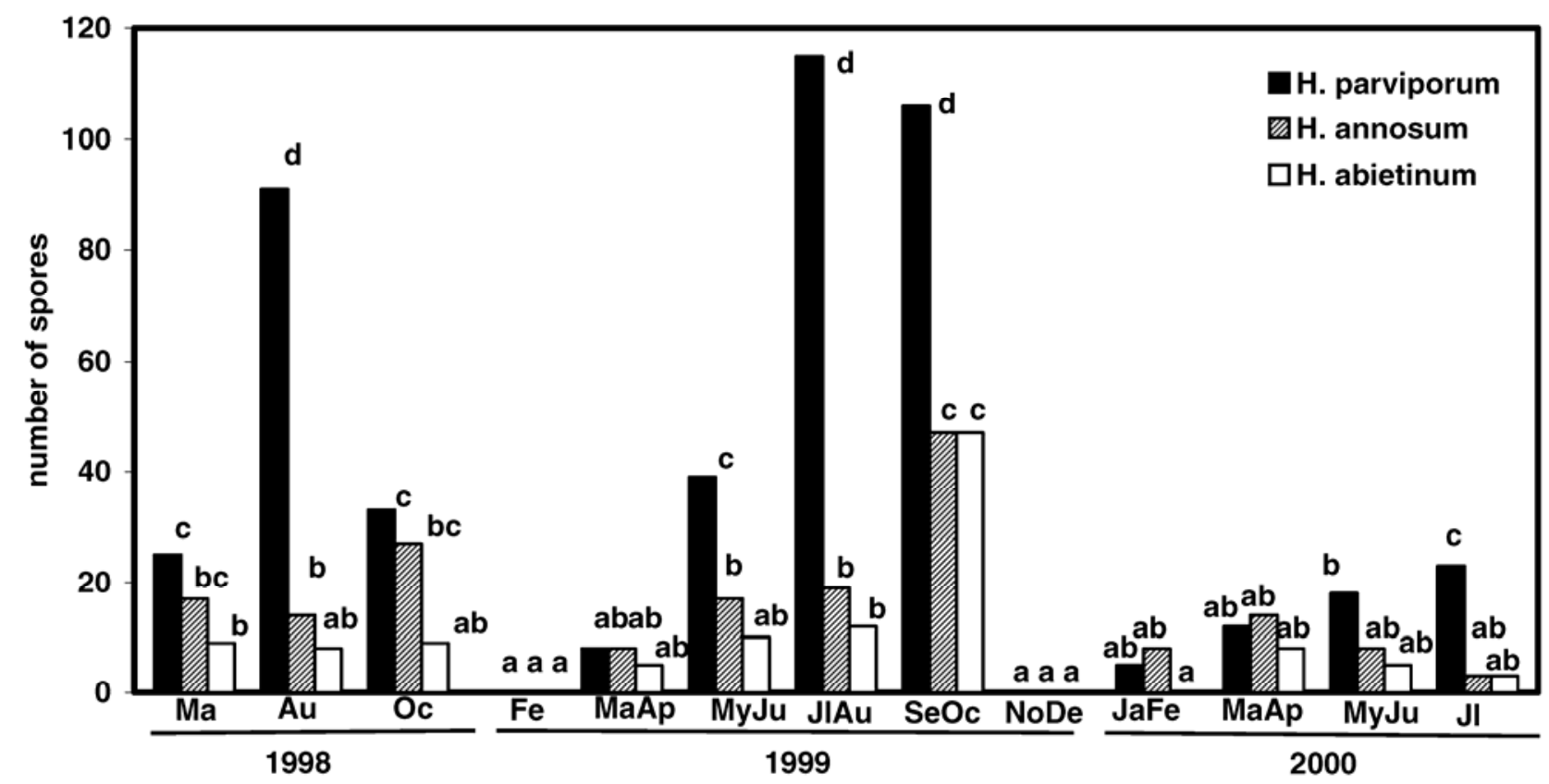

Fig. 5. Frequency of spores of the three species of Heterobasidion at different periods at the Aymavilles site determined with wood disk samples. Samplings were performed in 1998 to 2000. The abundance of spores was compared by the Mann-Whitney $U$ test $(n=773)$; bars marked by the same letter are not significantly different $(P \leq 0.05)$. Labels are as follows: $\mathrm{Ja}=\mathrm{January}, \mathrm{Fe}=$ February, $\mathrm{Ma}=$ March, Ap $=$ April, My $=\mathrm{May}, \mathrm{Ju}=\mathrm{June}, \mathrm{Jl}=\mathrm{July}, \mathrm{Au}=\mathrm{August}, \mathrm{Se}=\mathrm{September}$, $\mathrm{Oc}=$ October, $\mathrm{No}=$ November, and $\mathrm{De}=$ December 
sum. The increase of the latter species in spruce stands is well documented and may negatively affect the overall health of forest stands, given the aggressiveness in decaying wood by $H$. annosum, not only in pines but also in spruce stands.

\section{ACKNOWLEDGMENTS}

This research was supported by a grant of Regione Autonoma Valle d'Aosta/Région Autonome Vallée d'Aoste, Assessorato Agricoltura, Risorse Naturali e Protezione Civile/Assessorat de l'Agriculture, des Ressources Naturelles et de la Protection Civile. We thank the "Alta Valle Pesio e Tanaro Regional Park", R. Lussignoli, and G. Gonthier for technical assistance in the field work; and the senior editor and anonymous reviewers for critically reading this manuscript.

\section{LITERATURE CITED}

1. Berry, F. H., and Dooling, O. J. 1962. Fomes annosus on shortleaf pine in Missouri. Plant Dis. Rep. 46:886-887.

2. Brandtberg, P. O., Johansson, M., and Seeger, P. 1996. Effects of season and urea treatment on infection of stumps of Picea abies by Heterobasidion annosum in stands on former arable land. Scand. J. For. Res. 11:261-268.

3. Capretti, P., Korhonen, K., Mugnai, L., and Romagnoli, C. 1990. An intersterility group of Heterobasidion annosum, specialized to Abies alba. Eur. J. For. Pathol. 20:231-240.

4. Chase, T. E., and Ullrich, R. C. 1990. Genetic basis of biological species in Heterobasidion annosum: Mendelian determinants. Mycologia 82:6772 .

5. Chase, T. E., and Ullrich, R. C. 1990. Five genes determining intersterility in Heterobasidion annosum. Mycologia 82:73-81.

6. Driver, C. H., and Ginns, J. H., Jr. 1969. Ecology of Slash pine stumps: Fungal colonization and infection by Fomes annosus. For. Sci. 15:2-10.

7. Edmonds, R. L., and Driver, C. H. 1974. Dispersion and deposition of spores of Fomes annosus and fluorescent particles. Phytopathology 64:1313-1321.

8. Edmonds, R. L., Leslie, K. B., and Driver, C. H. 1984. Spore deposition of Heterobasidion annosum in thinned coastal western hemlock stands in Oregon and Washington. Plant Dis. 68:713-715.

9. Garbelotto, M., Ratcliff, A., Bruns, T. D., Cobb, F. W., and Otrosina, W. 1996. Use of taxon-specific competitive-priming PCR to study host specificity, hybridization, and intergroup gene flow in intersterility groups of Heterobasidion annosum. Phytopathology 86:543-551.

10. Gonthier, P., Garbelotto, M., and Nicolotti, G. 2003. Swiss stone pine trees and spruce stumps represent an important habitat for Heterobasidion spp. in subalpine forests. For. Pathol. 33:191-203.

11. Gonthier, P., Garbelotto, M., Varese, G. C., and Nicolotti, G. 2001. Relative abundance and potential dispersal range of intersterility groups of Heterobasidion annosum in pure and mixed forests. Can. J. Bot. 79:1057-1065

12. Holdenrieder, O. 1984. Untersuchungen zur biologischen Bekämpfung von Heterobasidion annosum an Fichte (Picea abies) mit antagonistischen Pilzen. II. Interaktionstests auf Holz. Eur. J. For. Pathol. 14:137153.

13. Ingold, C. T. 1971. Fungal Spores: Their Liberation and Dispersal. Clarendon Press, Oxford.

14. James, R. L., and Cobb, F. W. 1984. Spore deposition by Heterobasidion annosum in forests of California. Plant Dis. 246-248.

15. Johansson, M., and Brandtberg, P. O. 1994. Environmental conditions influencing infection of Norway spruce stumps by Heterobasidion annosum and effect of urea treatment. Pages 668-674 in: Proc. 8th IUFRO Conference of Root and Butt Rots. M. Johansson and J. Stenlid, eds. Swedish University of Agricultural Sciences, Uppsala, Sweden.

16. Kallio, T. 1970. Aerial distribution of the root-rot fungus Fomes annosus (Fr.) Cooke in Finland. Acta For. Fenn. 107:1-55.

17. Korhonen, K. 1978. Intersterility groups of Heterobasidion annosum. Commun. Inst. For. Fenn. 94:1-25.

18. Korhonen, K., Capretti, P., Karjalainen, R., and Stenlid, J. 1998. Distribution of intersterility groups in Europe. Pages 93-104 in: Heterobasidion annosum, Biology, Ecology, Impact and Control. S. Woodward, J. Stenlid, R. Karjalainen, and A. Hüttermann, eds. CAB International, New York.

19. Kuhlman, E. G., and Hendrix, F. F., Jr. 1962. A selective medium for the isolation of Fomes annosus. Phytopathology 52:1310-1312.

20. Meredith, D. S. 1959. The infection of pine stumps by Fomes annosus and other fungi. Ann. Bot. 24:63-78.
21. Mitchelson, K., and Korhonen, K. 1998. Diagnosis and differentiation of intersterility groups. Pages 71-92 in: Heterobasidion annosum, Biology, Ecology, Impact and Control. S. Woodward, J. Stenlid, R. Karjalainen, and A. Hüttermann, eds. CAB International, New York.

22. Morrison, D. J., and Johnson, A. S. L. 1970. Seasonal variation of stump infection by Fomes annosus in coastal British Columbia. For. Chron. 46:200-202.

23. Möykkynen, T., and Kontiokari, J. 2001. Spore deposition of Heterobasidion annosum coll. in Picea abies stands of north Karelia, eastern Finland. For. Pathol. 31:107-114.

24. Möykkynen, T., Von Weissenberg, K., and Pappinen, A. 1997. Estimation of dispersal gradients of S- and P-type basidiospores of Heterobasidion annosum. Eur. J. For. Pathol. 27:291-300.

25. Nicolotti, G., Gonthier, P., and Varese, G. C. 1999. Effectiveness of some biological and chemical treatments against Heterobasidion annosum on Norway spruce stumps. Eur. J. For. Pathol. 29:339-346.

26. Niemelä, T., and Korhonen, K. 1998. Taxonomy of the Genus Heterobasidion. Pages 27-33 in: Heterobasidion annosum, Biology, Ecology, Impact and Control. S. Woodward, J. Stenlid, R. Karjalainen, and A. Hüttermann, eds. CAB International, New York.

27. Otrosina, W. J., Chase, T. E., and Cobb, F. W. 1992. Allozyme differentiation of intersterility groups of Heterobasidion annosum isolated from conifers in the western United States. Phytopathology 82:540-545.

28. Pratt, J. E., and Greig, B. J. W. 1988. Heterobasidion annosum: Development of butt rot following thinning in two young first rotation stands of Norway spruce. Forestry 61:339-347.

29. Punter, D. 1970. Fomes annosus in eastern Canada. Pages 156-170 in: Root Diseases and Soil-Borne Pathogens. T. A. Toussoun, R. V. Bega, and P. E. Nelson, eds. University of California Press, Berkeley.

30. Redfern, D. B., and Stenlid, J. 1998. Spore dispersal and infection. Pages 105-124 in: Heterobasidion annosum, Biology, Ecology, Impact and Control. S. Woodward, J. Stenlid, R. Karjalainen, and A. Hüttermann, eds. CAB International, New York.

31. Reynolds, G., and Wallis, G. W. 1966. Seasonal variation in spore deposition of Fomes annosus in the coastal forests of British Columbia. Can. Dep. For. Bimon. Res. Note 22:6-7.

32. Rishbeth, J. 1951. Observations on the biology of Fomes annosus, with particular reference to east Anglian pine plantation. (II) Spore production, stump infection, and saprophytic activity in stumps. Ann. Bot. 15:1-21.

33. Rishbeth, J. 1957. Some further observations on Fomes annosus Fr. Forestry 30:69-89.

34. Rishbeth, J. 1959. Dispersal of Fomes annosus Fr. and Peniophora gigantea (Fr.) Massee. Trans. Br. Mycol. Soc. 42:243-260.

35. Ross, E. W. 1973. Fomes annosus in the southeastern United States: Relation of environmental and biotic factors to stump colonization and losses in the residual stand. U.S. Dep. Agric. For. Serv. Technol. Bull. 1459.

36. Russell, K. W., Wood, R. E., and Driver, C. H. 1973. Fomes annosus stump infection in Ponderosa pine sapling stands of eastern Washington. Washington (State) Dep. Nat. Res. Rep. 27.

37. Schönhar, S. 1980. Study of the infection by Fomes annosus of fresh stumps in Norway spruce afforestations during winter. Allg. Forst. Jagdztg. 151:153-154.

38. Sinclair, W. A. 1964. Root- and butt-rot of conifers caused by Fomes annosus, with special reference to inoculum dispersal and control of the disease in New York. Cornell Univ. Agric. Exp. Stn. Mem. 391.

39. Stambaugh, W. J., Cobb, F. W., Jr., Schmidt, R., and Krieger, F. C. 1962. Seasonal inoculum dispersal and white pine stump invasion by Fomes annosus. Plant Dis. Rep. 46:194-198.

40. Stenlid, J. 1994. Regional differentiation in Heterobasidion annosum. Pages 243-248 in: Proc. 8th IUFRO Conference of Root and Butt Rots. M. Johansson and J. Stenlid, eds. Swedish University of Agricultural Sciences, Uppsala, Sweden.

41. Stenlid, J., and Redfern, D. B. 1998. Spread within the tree and stand. Pages 125-141 in: Heterobasidion annosum, Biology, Ecology, Impact and Control. S. Woodward, J. Stenlid, R. Karjalainen, and A. Hüttermann, eds. CAB International, New York.

42. Stenlid, J., and Swedjemark, G. 1988. Differential growth of S- and Pisolates of Heterobasidion annosum in Picea abies and Pinus sylvestris. Trans. Br. Mycol. Soc. 90:209-213.

43. Swedjemark, G., and Stenlid, J. 1993. Population dynamics of the root rot fungus Heterobasidion annosum following thinning of Picea abies. Oikos $66: 247-254$.

44. Sylvestre-Guinot, G., and Delatour, C. 1978. Recherches sur les variations saisonnières de l'inoculum aérien du Fomes annosus (Fr.) Cooke dans l'est de la France. Ann. Sci. For. 35:151-163.

45. USDA Natural Resources Conservation Service. 1978. Keys to Soil Taxonomy. 8th ed. Pocahontas Press, Blacksburg, VA. 